\title{
Egy trauma-tudatos gyermekvédelmi rendszer kialakítása - útmutató ismertetés
}

\author{
Developing a trauma-informed child welfare system - description \\ Ismerteti: $\quad$ Oláh Barnabás $\square$ \\ Debreceni Egyetem, Népegészségügyi Kar, Magatartástudományi Intézet
}

Szerző: U.S. Department of Health and Human Services, Children's Bureau

Megjelenés: Child Welfare Information Gateway. 2015. https://www.childwelfare.gov/pubpdfs/trauma informed.pdf (Elérve: 2018. 05 25.)

Beküldve: 2018. 06. 11.

doi: $10.24365 /$ ef.v59i4.314

Kulcsszavak: trauma, gyermekkori bántalmazás, elhanyagolás, gyermekvédelem, traumatudatos

Keywords: trauma, child abuse, neglect, child welfare system, trauma-informed

\section{BEVEZETÉS}

A gyermekkori bántalmazás és elhanyagolás nagymértékben traumatizáló lehet és súlyosan károsithatja mind a testi, mind a pszichés egészséget. A traumatizáció rendkívül gyakori jelenség a gyermekvédelemben élő gyermekek körében. A nevelőszülői gondozásba kerülő gyermekek, az áthelyezést megelőzően általában többszörösen élnek át gondozójuk által elkövetett traumatikus eseményeket. ${ }^{1}$ Ebben az esetben ún. "hozott” traumáról beszélhetünk. Az áthelyezéssel járó szeparáció és veszteségélmény már maga a rendszer múködése által „szerzett” trauma, ami akár tovább súlyosbíthatja a korábbi traumatikus események következményeit. ${ }^{2}$ Stein és munkatársai kutatásában a nevelőszülőknél élő gyermekek között 10-ből 9 volt már kitéve a gyermekkori családon belüli bántalmazás valamely típusának. ${ }^{3}$ Hazánkban a gyermekvédelemben élő gyermekek száma kb. 23.000 fö, a nevelésbe vétel oka pedig 76\%-ban elhanyagolás vagy egyéb bántalmazás. ${ }^{4,5}$
Ennélfogva alapvető fontosságú a traumára való fokozott odafigyelés a gyermekvédelmi rendszerben. E mellett különböző módszerek segítségével, rendszerszintű változtatásokra van szükség a hozott és a rendszer múködése által szerzett traumák egészségre kifejtett súlyos következményeinek megelőzésére, mérséklésére és feldolgozására.

Ez a rövid iránymutatás sorra veszi azon fontosabb módosításokat, amelyek révén a gyermekvédelmi rendszer tudatosabb és válaszkészebb tud lenni a trauma tekintetében. A traumának és hatásainak rövid ismertetése után a közlemény leírást ad arról, hogy melyek azok az elsődleges területek a rendszeren belül, ahol leginkább intézkedésekre van szükség. Ezen területek a következők: munkaerőfejlesztés, felismerés és értékelés, adatrendszerek, bizonyítékokon alapuló kezelések és finanszírozás. Jelen ismertetés az egészségfejlesztéshez közvetlenebbül kapcsolódó területeket részletezi. Ezek a munkaerő-fejlesztés, a trauma felismerése, értékelése és kezelése. 


\section{TRAUMA ÉS KÖVETKEZMÉNYEI}

„Azok az események, eseménysorozatok vagy körülmények összessége, amelyeket az egyén fizikailag vagy emocionálisan károsnak vagy életveszélyesnek él meg személyes traumához vezethetnek, amennyiben annak tartós ártalmas hatása van az egyén funkcionálására és mentális, fizikai, szociális, emocionális vagy spirituális jóllétére nézve". ${ }^{6} \mathrm{Az}$ egyszeri traumatikus eseményt követő traumát (pl. autóbaleset) akut traumának nevezzük. A többféle traumatikus eseményből eredő traumát komplex traumának tekintjük. A gyermekkorban átélt bántalmazás általában többféle, ismétlődő, krónikusan fennálló, interperszonális természetű és pervazív, azaz a személyiségfejlődés összes aspektusára kihat. ${ }^{7}$ A közlemény az alábbi példákat sorolja fel, mint a traumatizáció által leginkább károsuló funkciók: érzelmi válaszok, gondolkodás, tanulás, koncentrációs képesség, impulzuskontroll, énkép, kötődés és szociális kapcsolatok. Problémák széles köre köthető a gyermekkori bántalmazás és elhanyagolás hosszú távú következményei közé. Ilyenek például a függőségek, depresszió, szorongás, kockázatvállaló magatartás, amelyek további megbetegedések kialakulási esélyét növelik, mint például elhízás, diabétesz, szívbetegségek, daganatos megbetegedés, továbbá a várható élettartam is csökkenhet. ${ }^{8}$ Nem minden gyermek esetében vezet a trauma súlyos következményekhez, hatása ugyanis függ a traumatikus esemény átélésekor betöltött életévtől, a trauma gyakoriságától és észlelt súlyosságától, a gyermek belső érzékenységétől. Közrejátszanak még olyan protektív tényezők is, mint például a pozitív szociális kapcsolatok megléte, a fizikai egészségi állapot és a hatékony megküzdési stratégiák.

\section{A TRAUMA-TUDATOSSÁG GYAKORLATI MEGVALÓSÍTÁSA A GYERMEKVÉDELMI RENDSZERBEN}

A trauma-tudatos gyermekvédelmi rendszer kialakítására való törekvések az utóbbi évtizedben indultak el Amerika egyes államaiban, a National Child Traumatic Stress Network (Gyermekkori Traumatikus Stressz Nemzeti Hálózata) kezdemé- nyezésére. A trauma-tudatos gyermek- és családsegítő rendszer kiemelt figyelmet fordít a traumatikus stressz hatásainak felismerésére és kezelésére mindazok körében, akik a rendszerrel kapcsolatban állnak. A rendszeren belüli programok és ügynökségek a szervezeti kultúrájukba, az eljárásmódjukba és a gyakorlatukba egyaránt beépítik a traumára való fokozott odafigyelést, a traumával kapcsolatos tudást és készségeket.

A trauma-tudatos rendszertől várt eredmények a következők: kevesebb gyermek szorul rá krízisintervencióra, a pszichotrópikus gyógyszerek csökkent használata, kevesebb áthelyezés történik, csökken a nevelőszülői gondozásban eltöltött idő, javul a funkcionalitás és fokozódik a jóllét.

A rendszer átszervezésének és múködtetésének alapjait, az iránymutatásokat a Gyermekjóléti Trauma Tréning Eszköztár foglalja magába. ${ }^{9}$

A folytatásban a kiadvány rövid leírást ad a trauma-tudatos rendszer kialakításának módjáról és kulcsterületeiről.

\section{A munkaerő fejlesztése}

A legfontosabb lépés a traumáról való gondolkodás megváltoztatása a rendszer összes érintettje körében. Paradigmaváltás az alábbi szinteken:

- "Trauma-lencse": a foglalkoztatottaknak, a gondozóknak és családoknak egy "traumalencsén" keresztül kell szemlélni a történéseket. Át kell értékelni a gyermekek viselkedését és nem úgy kell rájuk tekinteni, mint „rossz gyermekekre”, hanem tudatában kell lenniük annak, hogy a rossz magatartás egy lehetséges, de reverzibilis (visszafordítható) következménye a traumának. Nem azt kell kérdezni a gyermektől, hogy „Mi baj van veled?", hanem azt, hogy "Mi történt veled?".

- Új cél a gondozásban: eddig a gyermek fizikai biztonságának megteremtésre volt a fő cél, ezt ki kell terjeszteni a trauma gyógyítására, a szociális és emocionális jóllét biztosítására.

- Fókusz a korai intervencióban: minél előbb azonosítani és kezelni kell a traumatizáltságot, megelőzve vagy mérsékelve ezáltal a súlyos hosszú távú következményeket.

- Odafigyelés az intergenerációs traumára: figyelembe kell venni, hogy nemcsak a 
gyermekek, hanem a családtagjaik is lehetnek traumatizáltak, ami eredményezheti a helytelen bánásmódot.

- A másodlagos traumatizáció figyelembe vétele és kezelése: az egyes tragikus élettörténetek komoly traumatikus stresszt válthatnak ki a nevelőszülőkből, a gondozókból és szakemberekből egyaránt.

\section{Tréningek szervezése és a pszichoedukációi fontossága:}

- A nevelő és örökbefogadó szülők számára követelmény pszichoedukáción való részvétel, amely az alábbi témákat érinti: trauma alapismeretek, trauma hatásai a gyermekekre, traumát kiváltó tényezők, traumához kapcsolódó viselkedés felismerése és hatékony kezelése.

- A szakemberek és a foglalkoztatottak számára szakmai tréningek szervezése történik. A tréningek legfontosabb témái: trauma alapismeretek, trauma felismerése, gyermekek fizikai és pszichológiai szükségletei, reziliencia (rugalmas ellenálló képesség) erősítésének módjai, mikor, hogyan és hova lehet továbbutalni a gyermeket bizonyítékokon alapuló terápiára, traumatizált szülőkkel való együttmúködés. Tréning után további segítség biztosítása, pl. szupervízió.

A trauma korai felismerése és folyamatos szürése alapvető fontosságú a trauma-tudatos gyermekvédelmi rendszerben. Bekerüléskor, periodikusan ismételve és bizonyos stresszes események után ( $p l$. áthelyezés) egyaránt fel kell mérni a traumatizációt.

- Célok: a traumával kapcsolatos szükségletek felismerése, fejlődés vagy visszaesés monitorozása, tünetek azonosítása, a súlyosan traumatizált egyének szürése, további terápia szükségességének megállapítása. Mentális egészség és funkcionalitás értékelése, mérése különböző módszerekkel - akár diagnosztikus interjú segítségével.
Az értékelő eljárások a terápia tervezésének alapjai lehetnek. A terápia hatékonyságának ellenőrzésére utánkövetés alkalmazandó.

- A vizsgálati eszközök kiválasztásánál a következő szempontokat kell figyelembe venni: rövidség, idősebb és fiatalabb gyermekekre differenciált eljárások, internalizáló (a belső érzelmi életben megnyilvánuló) és externalizáló (a külső viselkedésben megnyilvánuló) tünetek együttes feltárása, költséghatékonyság, könnyű adminisztrálhatóság, megfelelő pszichometriai jellemzők: érvényesség, megbízhatóság, szenzitivitás (traumatizáltak esetében pozitív teszteredmény), specificitás (nem traumatizáltak esetében negatív teszteredmény).

\section{Bizonyítékokon alapuló eljárások a trauma kezelésére}

Az alábbi pszichoterápiás eljárások traumával szembeni hatékonysága mellett erős empirikus bizonyítékok szolgálnak, így megfelelő módszerek lehetnek a gyermekvédelemben a súlyosan traumatizált gyermekek gyógyítására:

- Traumafókuszú kognitív viselkedésterápia (TF-CBT): Központjában a negatív emocionális és viselkedéses reakciók csökkentése áll, azáltal, hogy a terápiában sor kerül a traumához kapcsolódó téves hiedelmek és attribúciók (oktulajdonítások) azonosítására és korrigálására.

- Szülő-gyermek interakciós terápia (PCIT): Családközpontú terápiás eljárás, bántalmazott és veszélyeztetett helyzetben lévő 2-8 éves gyermekek és gondozóik számára. A terápiában a terapeuta coachingolja (fejleszti) a szülőt, miközben interakciót létesít a gyermekkel.

- Szemmozgásokkal történő deszenzitizálás és újrafeldolgozás (EMDR): A traumatikus emlékhez kötődő emocionális distressz (negatív érzelmi feszültség) csökkentését célzó integrált módszer.

\footnotetext{
' Egy adott pszichés problémával és annak kezelésével kapcsolatos fevilágosítás és oktatás.
} 


\section{TANULSÁGOK A HAZAI SZAKEMBEREK SZÁMÁRA}

Hazánkban a gyermekvédelmi rendszerben dolgozók többnyire csak keveset tudnak a trauma súlyos viselkedéses és mentális következményeiről, kezeléséről. A rendszer összes foglalkoztatottjának tisztában kell lennie azzal, hogy a legtöbb gyermeknél magával a kiemeléssel a probléma nem oldódik meg, nem elég pusztán a fizikai biztonság megteremtésére törekedni, ugyanis a kezelés nélkül hagyott traumatizációnak súlyos életre szóló következményei vannak. A gyermekvédelemben széleskörű együttmúködésre és koordinált, rendszerszintű változásokra van szükség a trauma hatékony kezelésére, következményei megelőzésére és a testilelki egészség fejlesztésére, fenntartására. Mindehhez jó szakmai útmutatásokat nyújtanak a kiadványban ismertetett módszerek, eszközök és eljárások.

\section{HIVATKOZÁSOK}

${ }^{1}$ Oswald SH, Fegert JM, Goldbeck I. Posttraumatic stress symptoms in foster children following maltreatment and neglect. Verhaltenstherapie. 2010;20(1): 37-44.

${ }^{2}$ Greeson J, Briggs EC, Kisiel CL, et al. Complex Trauma and Mental Health in Children and Adolescents Placed in Foster Care: Findings from the National Child Traumatic Stress Network. Child Welfare. 2011;90(6): 91-108.

${ }^{3}$ Stein B, Zima B, Elliott M, et al. Violence exposure among school- age children in foster care: Relationship to distress symptoms. J Am Acad Child Adolesc Psychiatry. 2001;40(5): 588-594.

${ }^{4}$ KSH (Központi Statisztikai Hivatal). A gyermekvédelmi szakellátásban részesülő fiatalok (1990-2016). 2016.

http://www.ksh.hu/docs/hun/xstadat/xstadat eves/i fsg001.html (Elérve: 2018. 05. 25.)

${ }^{5}$ KSH (Központi Statisztikai Hivatal). Állami gondoskodástól a mai gyermekvédelemig. 2012.

https://www.ksh.hu/docs/hun/xftp/idoszaki/pdf/allamigondoskodas.pdf (Elérve: 2018. 05. 25.)

${ }^{6}$ Substance Abuse and Mental Health Services Administration. SAMHSA's concept of trauma and guidance for a traumainformed approach. 2014. https://store.samhsa.gov/shin/content/SMA14-4884/SMA14-4884.pdf (Elérve: 2018. 05. 25.)

${ }^{7}$ National Child Traumatic Stress Network. Complex trauma: Facts for caregivers. 2014. https://www.nctsn.org/sites/default/files/resources//complex trauma caregivers.pdf (Elérve: 2018. 05. 25.)

${ }^{8}$ Council on Children and Families. Adverse childhood experiences among New York's adults. 2010. http://ccf.ny.gov/files/4713/8262/2276/ACE BriefTwo.pdf (Elérve: 2018. 05. 25.)

${ }^{9}$ Child Welfare Collaborative Group, National Child Traumatic Stress Network, California Social Work Education Center. Child welfare trauma training toolkit: Participant manual (1st ed.). National Center for Child Traumatic Stress, Los Angeles, CA, \& Durham, NC. 2013. 